\title{
MAGYARORSZÁGI GYÁRTÓEGYSÉGEK IPAR 4.0 GYAKORLATÁNAK ELEMZÉSE - TECHNOLÓGIA, STRATÉGIA, SZERVEZET
}

\author{
ANALYSIS OF THE INDUSTRY 4.0 PRACTICE OF THE HUNGARIAN \\ PRODUCTION UNITS - TECHNOLOGY, STRATEGY, ORGANIZATION
}

Bár számos koncepcionális tanulmány létezik az Ipar 4.0 (14.0) technológiáiról és empirikus eredmények is vannak konkrét 14.0 alkalmazásokról, a jelenlegi irodalom csak felületes képet ad a szervezeti szintű 14.0 transzformációkról. A cikk célja, hogy az 14.0 bevezetésére kialakított keretrendszer alapján bemutasson három esettanulmányt. A szerzők eredményei alapján még a nagyvállalatok is küzdenek az 14.0-val. Mindenesetre, nekik már van digitális stratégiájuk, digitális transzformációs tervük és digitális kormányzásuk. De a digitalizáció egyelőre egy különálló osztály kompetenciája. Az I4.0 erőfeszítések rendszerint a szervezeten belülre, a termelésre irányulnak. A helyettesítő technológiák kedvező, jól becsülhető megtérüléssel kecsegtetnek, de nem fognak áttörő transzformációhoz vezetni.

\section{Kulcsszavak: digitalizáció, Ipar 4.0, stratégia, szervezet, technológia, esettanulmány}

Although there are conceptual works on key 14.0 technologies and empirical findings about specific 14.0 applications, current literature offers only superficial empirical findings about organisation wide 14.0 transformations. The authors' objective is to provide a framework for 14.0 implementation and discuss three case studies along the framework. Based on their findings, even the large companies struggle with 14.0. Nevertheless, they already have digital strategy, digital transformation plan, and digital governance. But digitalization is still in a separated department. Efforts are usually made internally, in manufacturing. Replacing technologies can provide good, easy to estimate return, but will not lead to breakthrough transformations.

Keywords: digitalisation, Industry 4.0, strategy, organization, technology, case study

\section{Finanszírozás/Funding:}

A kutatást az EFOP-3.6.2-16-2017-00007 azonosító számú, Az intelligens, fenntartható és inkluzív társadalom fejlesztésének aspektusai: társadalmi, technológiai, innovációs hálózatok a foglalkoztatásban és a digitális gazdaságban című projekt támogatta. A projekt az Európai Unió támogatásával, az Európai Szociális Alap és Magyarország költségvetése társfinanszírozásában valósul meg.

This research was supported by project EFOP-3.6.2-16-2017-00007 Aspects of developing a smart, sustainable and inclusive society: social, technological, innovative networks in employment and the digital economy.

The project is funded by the European Union and co-financed by the European Social Fund and the budget of Hungary.

\section{Szerzők/Authors:}

Dr. Demeter Krisztina, egyetemi tanár, Budapesti Corvinus Egyetem, (krisztina.demeter@uni-corvinus.hu) Dr. Losonci Dávid, egyetemi docens, Budapesti Corvinus Egyetem, (david.losonci@uni-corvinus.hu) Dr. Szász Levente, egyetemi tanár, Babeş-Bolyai Tudományegyetem, (szasz.levente@yahoo.com) Dr. Rácz Béla-Gergely, egyetemi adjunktus, Babeş-Bolyai Tudományegyetem, (raczbela@gmail.com)

A cikk beérkezett: 2019.07.09-én, javítva: 2019.12.17-én, elfogadva: 2020.03.16-án. This article was received: 09. 07. 2019, revised: 17. 12. 2019, accepted: 16.03.2020.

A digitalizáció radikális hatásai már jó ideje tapasztalhatók az üzleti életben, így a feldolgozóiparban is. Elég, ha csak a digitális tartalmakra épített üzleti modellek térnyerésére gondolunk, amelyek a nyomtatott termékeket (újságok), vagy a zeneipart kiszolgáló gyártócégeket érintették. Ha azonban kiemelten csak a gyártócégek müködtetésének és előállítási folyamatainak digitális alapokra helyezését tekintjük, akkor a feldolgozóipar az átmenetnek még csak az elején jár. Sőt, egyelőre a feldolgozóipar digitalizációjának pontos tartalma és várható hatásai is 
élénk diskurzus tárgyát képezik (Horváth \& Szabó, 2019; Nagy, 2019).

Az anyagáramlási folyamatok jelentős szerepe miatt a digitalizációs trendet a feldolgozóiparban az ún. Ipar 4.0 (I4.0) jelenség foglalja magába (Lasi, Fettke, Kemper, Feld, \& Hoffmann, 2014; Valenduc \& Vendramin, 2016). Az I4.0 felöleli az új és/vagy megújult digitális és fizikai technológiákat is. Víziójában az I4.0 kiber-fizikai technológiákat használ azzal a céllal, hogy személyre szabott, digitális szolgáltatási tartalommal felruházott termékeket kínáljon egy újratervezett értékláncban (vertikális integráció), egy átstrukturált ellátási láncon belül (horizontális integráció), amelyben minden résztvevő össze van kapcsolva és megosztja egymással az információt (Brettel, Friederichsen, Keller, \& Rosenberg, 2014; Schlechtendahl, Keinert, Kretschmer, Lechler, \& Verl, 2015; Demeter, Losonci, Nagy, \& Horváth, 2019).

Ma már számos koncepcionális tanulmány létezik az I4.0 kulcstechnológiáiról (Davies, 2015; Ghobakhloo, 2018) és egy-két jól dokumentált empirikus eredmény is született konkrét I4.0 alkalmazásokról (Porter \& Heppelmann, 2014). Söt a folyamatok teljesítményre gyakorolt hatásairól is van átfogó ismeretünk (López-Gómez, McFarlane, O'Sullivan, \& Velu, 2018). Bár az átmenet központi szereplői a gyártóvállalatok, ezen cégek ténylegesen megélt I4.0 transzformációjának komplex leírásáról csak meglehetösen homályos képpel rendelkezünk.

Cikkünk a kontingenciaelméletre építve (Donaldson, 2001; Sousa \& Voss, 2008) vizsgálja a gyártóegységek alkalmazkodását az üzleti környezetben tapasztalt technológiai változásokra a technológiahasználat, a stratégiaalkotás és a szervezeti változások keretrendszerében és bemutatja a tapasztalt hatásokat is. A cikk fö hozzáadott értéke, hogy - a korábbi cikkekkel ellentétben, a keretrendszer segítségével - komplexen ragadja meg és elemzi az átmenetet. A keretrendszert három Magyarországon működő gyártónál készített esettanulmány alapján tárgyaljuk.

Cikkünk először az irodalmat tekinti át a keretmodell egyes pillérei mentén. Ezt követően kutatási modellünk leírása következik. A módszertani megfontolásokat az egyes gyártóegységeknél tapasztalt változás leírása, majd ezek összevetése követi. Cikkünket az összegzés zárja, amelyben kitérünk a menedzsereknek szóló javaslatokra és a további kutatási lehetőségekre is.

\section{Az Ipar 4.0 a digitális gazdaságban}

Keretmodellünkhöz (1. ábra) kapcsolódóan az irodalomelemzésben a technológiákra, a stratégiaalkotásra és a szervezeti változásokra térünk ki. Ez az elemzési keret szintetizálja a vállalati szintủ I4.0 érettségi modellek legfontosabb közös dimenzióit (Fettermann, Sá Cavalcante, de Almeida, \& Tortorella, 2018; Geissbauer, Vedso, \& Schrauf, 2016; Viharos, Soós, Nick, Várgedő, \& Beregi, 2017). A kontingenciaelmélet a változásokhoz hatásokat is kapcsol. Az I4.0 hatásai közül a munkavállalókra és a teljesítményre gyakorolt hatásokat emeljük ki.
1. ábra

\section{A kutatási keretmodell}

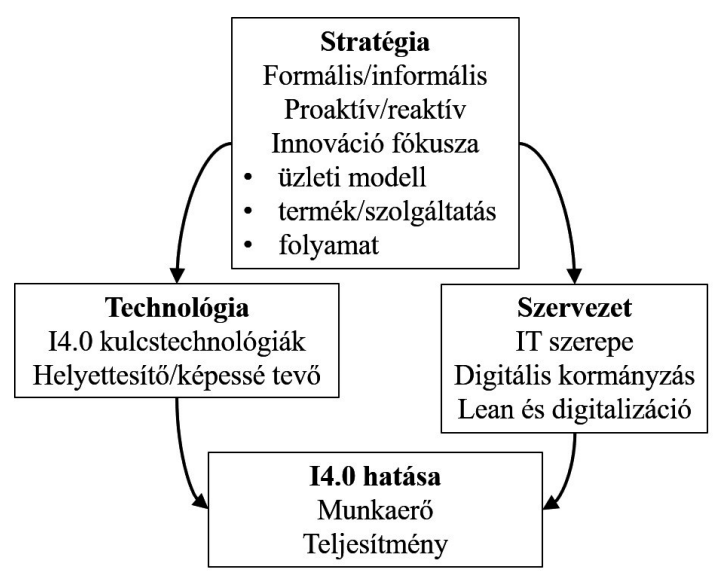

Forrás: saját szerkesztés

\section{Stratégia}

A stratégia elemzése kapcsán foglalkozunk az innovációs fókusszal, illetve a stratégiaalkotás folyamatának jellemzöivel.

\section{Az Ipar 4.0 által támogatott innováció jellege}

A legkomplexebb változást az üzleti modell innovációja eredményezi (Horváth, Móricz, \& Szabó, 2018): számottevően átalakítja az érintettekkel a kapcsolatot, és egészen újfajta müködési rendhez vezethet (pl. új folyamatok, új versenytársak) egy adott iparágban, vagy új iparágat is létrehozhat. Szükségszerüen okos termékekre és szolgáltatásokra épül, amelyeket a második fajta innovációnak tekintünk. Végül, az I4.0 folyamatinnovációban való kiaknázása is egy müködőképes alkalmazási stratégia. Ez utóbbi esetben a fö cél, hogy az értéklánc folyamatait rendszerint a belsőket - hatékonyabbá tegyék. Bár vannak esetek, amikor új üzleti modelleket és értékajánlatokat (értsd: okos termékeket és szolgáltatásokat) fejlesztettek a cégek, a gyártó vállalatok az I4.0 alkalmazásával rendszerint a belső folyamatok integrációjára és jobb müködési teljesítményre törekednek (López-Gómez et al., 2018). A folyamatinnovációs megközelítés elég szük interpretácioját adja a technológiákban rejlő lehetőségeknek, mégis úgy gondoljuk, hogy a technológiák ilyen típusú megközelítése hozta el az I4.0 fogalom berobbanását a köztudatba. Ugyanakkor hiba lenne csak ezt az orientációt követni a mindennapokban.

\section{Az Ipar 4.0-val kapcsolatos stratégiaalkotás}

A kontingenciaelmélet alapállása szerint a külső környezetben bekövetkező változásokat a stratégiának kell lekövetnie, melynek megvalósítása érdekében megváltoznak a szervezeti és müködési folyamatok, illetve mindezeknek köszönhetően a teljesítmény. Nem meglepő tehát, hogy az elérhető technológiák alkalmazása és a vállalati stratégia kialakítása kéz a kézben járnak. Így a stratégia alakításának legfeljebb a milyensége lehet kérdéses. Ennek kapcsán egyesek azt emelik ki, hogy a stratégiai orientációnak vál- 
toznia kell, hogy az új technológiák hatékonyabb bevezetésének motorja legyen (Stock \& McDermott, 2001; Lewis \& Boyer, 2002). Mások azt hangsúlyozzák, hogy a technológiák bevezetési stratégiájának és a vállalati (üzleti) stratégiáknak összhangban kell lenniük ahhoz, hogy bármilyen új technológiát sikerrel lehessen bevezetni (Kotha \& Swamidass, 2000; Pires \& Aisbett, 2003). A nagyjából egy irányba mutató megfontolások mellett is további elemzéseket igényel a téma, mivel a stratégia és a technológia bevezetése közötti kapcsolat nem mindig egyértelmü (Lucianetti, Jabbour, Gunasekaran, \& Latan, 2018). Ez különösen igaz az újonnan megjelent I4.0 technológiákra és megoldásokra.

A stratégiai tervezés két fontos szempontját emeljük ki az új technológiák alkalmazásával kapcsolatosan. Az első szempont a stratégiai tervezés proaktív vagy reaktív természetével foglalkozik (King \& Teo, 2000). Proaktív stratégiánál a vállalat aktív szerepet játszik a stratégiai innovációban. Ez azt jelenti, hogy a versenytársakat megelőzve új folyamatokat és termékeket hoz létre azzal a céllal, hogy megragadja a felmerülő lehetőségeket és versenyelőnyt szerezzen a piacon. A reaktív stratégia szerint a vállalat szerepe passzív. Ilyenkor a vállalat stratégiai viselkedését a külső behatásokhoz igazítja, a környezetben megfigyelt változásokra reagál vagy a versenytársak által támasztott kihívásokra válaszol (Chen, Chang, \& Wu, 2012).

Az új technológia alkalmazásával kapcsolatos stratégiai tervezés másik szempontja a folyamat formális vagy informális jellegével foglalkozik (O'Regan \& Ghobadian, 2002). A formális stratégiai tervezés egy iteratív, átfogó, szisztematikus megközelítést jelent, amellyel a vállalat vezetése analitikusan meghatározza a szervezet stratégiai irányvonalát (Galbraith, 2010). Ezzel szemben, az informális tervezés csak a múltbeli tapasztalatokon és a szervezeti tagok intuícióin nyugszik, amelyek alapján a jövőre vonatkozó döntéseket meghozzák. Az informális tervezés így azt is jelenti, hogy a cégek nem tervezik meg elöre szisztematikusan stratégiájukat; a stratégiai lépések és kiigazítások a vállalat tapasztalataira építenek, amelyekkel a vállalat a stratégiai döntés pillanatában rendelkezik (Mintzberg \& Waters, 1985). Ez a különbség szorosan kapcsolódik a fentről-lefelé és lentről-felfelé (top-down/ bottom up) jellegü stratégia kialakításhoz. A fentről-lefelé irány mentén olyan funkcionális stratégia (benne a technológiai stratégia) jön létre, amely egy világosan megfogalmazott vállalati és üzleti stratégiából származik. A lentről-felfelé megközelítés alapján a stratégiai döntések idővel formálódnak és a szervezet mindennapi tapasztalatain alapulnak. Tehát, a fentről-lefelé stratégia egy formális, hierarchikus tervezési folyamat eredménye, míg a lentről-felfelé stratégia egy szervezet napi tevékenysége folyamán felhalmozott tapasztalat eredője (Slack, Chambers, \& Johnston, 2010).

Összességében, az I4.0 bevezetés stratégiai megközelítéseinek osztályozásakor érdemes tisztában lenni az innováció fókuszával, a stratégiai tervezés reaktív vagy proaktív jellegével, és a stratégiai tervezés formalitásával, ami szorosan kapcsolódik stratégiaalkotás fentről-lefelé és/vagy lentről-felfelé természetéhez.

\section{Az Ipar 4.0 technológiái}

Az I4.0 koncepció megjelenése azt mutatja, hogy a digitális és fizikai innováció gyártási környezetben mára kritikus tömeget ért el. A gyártóvállalatok termelési folyamataiban ma megjelenő kulcstechnológiák (1. táblázat) konszenzusosan összeszedhetök (Demeter et al., 2019). E technológiák alapozzák meg az I4.0 elveit (pl. horizontális és vertikális integráció (Ghobakhloo, 2018) és ezekre épülnek a konkrét I4.0 megoldások (pl. digitális minőségmenedzsment, prediktív karbantartás (Goran, LaBerge, \& Srinivasan, 2017)).

Az I4.0 kulcstechnológiák differenciáltabb megközelítését adja, ha a technológiákat érettségük alapján csoportosítjuk. Az egyes technológiák érettségéröl az irodalomban kevés szó esik, miközben az érettség determinálja, hogy mennyire széles körben terjedhetnek el ezek a technológiák, vagy mennyire számíthatunk ezekkel kapcsolatban „,csak” pilot projektekre. A kulcstechnológiák érettségét az új technológiák hype görbéje segítségével ragadjuk meg (Gartner, dátum nélk.). Az éves hype görbe sok új technológia aktuális helyzetét mutatja az ,életciklus” következő szakaszai alapján: innováció elsütése (innovation trigger), felfokozott várakozás csúcsa (peak of inflated expectations), kiábrándulás völgye (trough of disillusionment), felvilágosodás emelkedője (slope of enlightement) és termelékenység fennsíkja (plateau of productivity). Az elemzés elörejelzi, hogy időben mikor fog az adott technológia a termelékenység fennsíkjára érkezni. Annak érdekében, hogy a vizsgált technológiák érettségét megbecsüljük, három kiválasztott évre megnéztük a Gartner elemzését (2. ábra).

\section{2.ábra}

\section{Néhány 14.0 kulcstechnológia érettsége a Gartner-görbén}

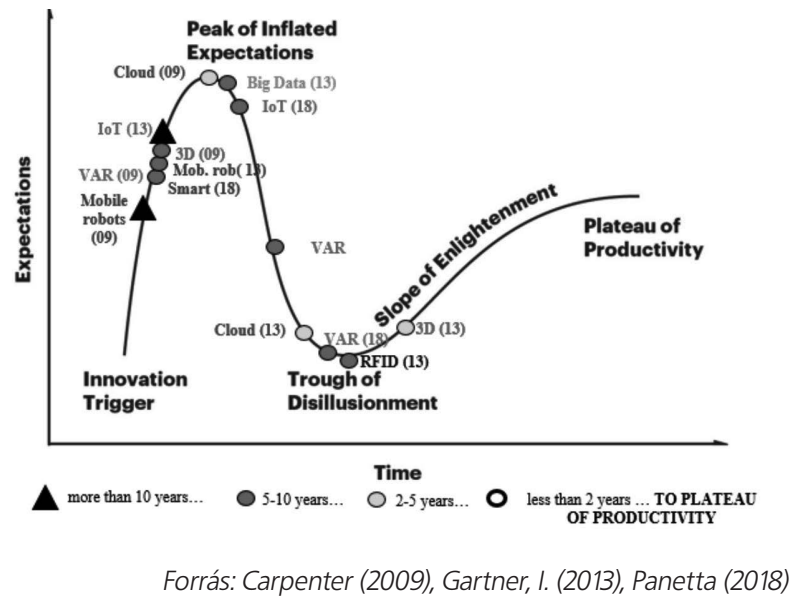

Hogy egy konkrét technológia érettségéröl dönteni tudjunk, megnéztük, megjelent-e a görbén (igen/nem), mikor jelent meg és mikorra várható, hogy a termelékenységi fennsíkra érkezik. A technológiákat a következő négy csoportba soroltuk:

1. Hosszú elötörténet és jól ismert technológiák: a szimuláció és modellezés, valamint a szenzorok (úgy általában) egyáltalán nem kerültek fel a görbére. 
Véleményünk szerint az újabb technológiák (pl. IoT, Big data) tovább erősíthetik ezeket: az IoT például lehetővé teszi nagy mennyiségü adat gyüjtését és inputként való használatát szimulációkban.

2. Érett I4.0 technológiák: egy évtizede már jelen vannak és az elörejelzések szerint már elérték a fennsík fázist. A felhö, a 3D nyomtatás, valamint a szenzorok közé sorolható RFID tartoznak ide.

3. Feltörekvő technológiák: számos jól ismert technológia (IoT, VAR, okos robotok) tartozik ebbe a csoportba, amelyeknek még hosszú idő kell, hogy a fennsíkra érjenek.

4. A Big data elemzés az utolsó két csoport között található. Rövid előtörténete ellenére már a következő évtized elejére termelékeny megoldássá válhat.

1. táblázat

\section{Az 14.0 kulcstechnológiáinak érettsége a Gartner elemzése alapján}

\begin{tabular}{|l|l|l|}
\hline \multicolumn{1}{|c|}{ Érettség } & \multicolumn{1}{|c|}{ I4.0 technológia } & Domináns jellemző \\
\hline \multirow{3}{*}{ Jól ismert } & szimuláció és modellezés & digitális \\
\cline { 2 - 3 } & szenzor & $\begin{array}{l}\text { kapcsolat a digitális és } \\
\text { fizikai között }\end{array}$ \\
\hline \multirow{2}{*}{ Érett } & felhő & digitális \\
\cline { 2 - 3 } & 3D & fizikai \\
\hline Kísérleti & Big data elemzés & digitális \\
\hline \multirow{3}{*}{ Feltörekvő } & Internet of Things & digitális \\
\cline { 2 - 3 } & virtuális valóság & digitális \\
\cline { 2 - 3 } & okos robotok & fizikai \\
\hline
\end{tabular}

Forrás: saját szerkesztés Gartner, I. (2013) alapján

Az 1. táblázat utolsó oszlopában szerepel, hogy mennyiben tekinthető az adott technológia digitálisnak vagy fizikainak. Ezt a beosztást Schwab (2016) csoportosítására építve készítettük.

Két tényezőt fontos kiemelni az érettség besorolással kapcsolatban. Egy-egy technológia ismertsége vagy érettsége még nem garancia arra, hogy széles körben használják a rájuk építő megoldásokat. A másik, hogy a szakértők azt sejtetik, hogy az I4.0 technológiák szigetszerü, szórványos használata nem fog szervezeti megújuláshoz vezetni, ezért rendszerint azt javasolják, hogy alakítson ki a vállalat egy stratégiát, ami több I4.0 kulcstechnológia kölcsönhatására épít (Ghobakhloo, 2018). Az I4.0 kulcstechnológiák eltérő érettségét látva ez nem is annyira könnyü feladat.

\section{Szervezeti változások}

A kontingencialista megközelítés szerint a technológia és a környezet változásaihoz a szervezetnek is illeszkednie kell (Gilchrist, 2016; Tornatzky \& Fleischer, 1990). Az I4.0 technológiákkal kapcsolatban a szervezeti kérdések leggyakrabban a szükséges kompetenciákkal és e kompetenciák struktúrában elfoglalt helyével foglalkoznak. E kérdéskörnek specifikus - de nem figyelmen kívül hagyható - leképeződése a digitálizáció és a lean kapcsola- tának elemzése, tekintve, hogy az elmúlt évtizedekben a lean menedzsment vált a gyártó vállalatok új müködési paradigmájává, ami a szervezetre is jelentős hatást gyakorol (De Toni \& Tonchia, 1996; Báthory, 2020). A szervezeti kérdések mellett az egyénekre gyakorolt hatások (kompetenciák, létszám) is előtérben vannak, amelyeket a következő alfejezetben tárgyalunk.

A digitalizációhoz szükséges kompetenciák vállalaton belüli helyével foglalkozó irodalom két témát emel ki: az egyik az IT-osztályok bővülő kompetenciáival foglalkozik, a digitális kormányzás (digital governance) pedig a technológiai ismereteknek a meglévő/új szervezeti egységekbe (de nem IT-be) való becsatornázására tesz javaslatot. Andersson és Tuddenham (2014) a digitalizációval kapcsolatban az IT jelentőségét emeli ki. Azt hangsúlyozzák, hogy a digitalizáció egy új alapokra épített (reinvented) IT-funkció részeként jelenhet meg. Meglátásuk szerint ugyanis a digitalizáció három eltérő módon hat az IT-re: (1) a digitalizáció egyre kifinomultabb technológiát követel, (2) magasabb IT-teljesítmény szükséges hozzá, (3) a digitalizáció azzal jár, hogy az IT-re a felső vezetés jobban figyel, mivel sokkal nagyobbá válik a tét, mint bármikor korábban.

Az IT-osztályon túlmutató változásokat feltételez, hogy a technológiai ismereteket a szervezetben széles körben hasznosítani kell. Sőt, a termelési hálózatokban való terjedése a vállalatkormányzási struktúrában is változással járhat. Gauger, Gehres, Quinn, Schmieg, \& Xu (2017) négy lépcsőt írnak le: az opportunista megoldás a funkcionális dominanciára épít, amikor a funkciókon belüli használatot nem egészíti ki koordináció, a transzformerek kifinomultabb technológiákat használnak és náluk előtérbe kerül a keresztfunkcionális koordináció is, amelyet a szervezet egészében a digitális transzformációs osztály (digital transformation office) és feje, a digitális igazgató (digital chief officer) irányít. A pacemakerek a digitalizáció komplexitását és a szervezeti koordináció szintjét is növelik, amely modellben a „kiválósági központ” (Centre of Excellence, CoE), vagy digitális „gépház” (powerhouse) a föszereplö, amely digitális termékinnovációban is gondolkodik. A digitalisták pedig már a techvállalatokhoz hasonlóan müködnek.

Az IT változása inkább egy alap, amely önmagában egy vállalat digitális transzformációjához kevés lehet. A transzformáció további dimenziói a változás gyorsaságával és a menedzsment hozzáállásával kapcsolatosak. Ahogyan Andersson és Tuddenham (2014) is kiemeli, a fö kihívás, hogy a szervezeti struktúrák kötöttek, így azok változása nem lehet olyan gyors, mint amit a digitalizáció szükségessé tenne. A szervezet alakítása nem csak struktúraalakítási kérdés, hiszen az a kulcsszereplők magatartásában is változást feltételez. Legner és szerzőtársai (2017) a sikeres digitális transzformációk mögött a felső vezetők direkt támogatását emelik ki, míg Horlacher és Hess (2016) a dedikált digitális igazgatókat említi. A sikeres digitális transzformáció szükséges, de nem elégséges feltétele, hogy a vezetők elsődleges prioritásként és ne „IT-erőfeszítésként” közelítsék meg azt (Andersson \& Tuddenham, 2014). 
A szervezeti struktúra jellege sem közömbös. Egy organikus, decentralizált szervezeti struktúra jól tudja támogatni a hatékony digitális transzformációt (Andersson \& Tuddenham, 2014). Az ilyen struktúrával rendelkező gyártóüzemek bizonyos fokig rugalmasak a munkavállalók felelősségét tekintve, és a vertikális kommunikáció mellett elősegítik az oldalirányú kommunikációt is (Baker, 2012). Más kutatások szerint nem feltétlenül mindig az organikus, decentralizált struktúra az üdvözítő. Bár az valóban jobban teljesít az innovációs folyamat adoptálási (döntési) fázisában, a mechanisztikus struktúra - a formális jelentési kapcsolatok, a centralizált döntéshozatal és a dolgozók egyértelmúen definiált szerepei révén - a bevezetési fázisban kedvezőbb (Zaltman, Duncan, \& Holbek, 1973).

A gyártóegységek szintjén a folyamatinnováció a lean programokban, illetve nemzetközi termelési hálózatokban a lean alapokra épített koordinációs eszközben, az ún. többgyáras fejlesztési programokban (multi-plant improvement program) ölt testet (Netland, 2013). A nagy termelő cégeknél kivétel nélkül találkozhatunk leanre épített fejlesztéssel, sok cégnél gyári szinten is dedikált lean osztályok működnek. Ahogyan a stratégiáról szóló részben bemutattuk, az Ipar 4.0 leggyakrabban a folyamatfejlesztéshez kapcsolódik a gyártók gyakorlatában. A két koncepció célrendszerének azonossága helyezi előtérbe kapcsolatuk elemzését. A lean irodalomban leginkább a digitális megoldások leant támogató hatásaival foglalkoznak (Buer, Strandhagen, \& Chan, 2018).

$\mathrm{Az}$ eddig bemutatott, a szervezeti változásokat átfogóan közelítő irodalom tapasztalatait használhatjuk a gyártóegység szintjén mutatkozó változások elemzésekor. Célzottan ugyanis ennek az elemzési szintnek a szervezeti adaptációról szóló szakirodalma még szegényes.

\section{Az 14.0 hatása}

A munkaerőre gyakorolt hatás alapján Acemoglu (2016; 2017) megkülönböztet helyettesítő (replacing) és képessé tevő (enabling) technológiákat. A képessé tevő technológiákat úgy körvonalazta, hogy azok “kibővitik a munkások képességeit, és lehetövé teszik számukra új funkciók végrehajtását, növelve a termelékenységet" (Acemoglu, 2017, p. 4). Például, a Big data analitika egy folyamatfigyelö rendszer, ami javítja a vezetői döntéseket a kapacitáskihasználással kapcsolatban. A helyettesítő technológiák „kifejezetten helyettesitik az embert néhány feladatban" (Acemoglu, 2017, p. 5). A robotok rendszerint ismétlődő feladatokat látnak el manuális (ipari robot), és kognitív (automatikus rendeléskezelés) környezetben egyaránt. Hosszú távon a mesterséges intelligencia ígérete, hogy helyettesíti az embert a kreatív kognitív feladatokban. Míg tehát a képessé tevő technológia növeli az össztermelékenységet, a helyettesítő technológia nem vezet az össztermelékenység növekedéséhez, csupán az ember-tőke arányt változtatja meg az előbbi rovására.

\section{A kutatás módszertana}

Kutatásunk fókuszában a digitális transzformáció komplex értékelése áll a vizsgált gyártóegységekben. Alapfeltevésünk, hogy a technológia áthatja a működési környezetet, így a kontingenciaelméletet követve megvizsgáljuk a szervezetben a stratégiai tervezés folyamatát, a szervezeti változásokat és az alkalmazott technológiákat. Várakozásaink szerint ezek a változások a munkaerőre és a teljesítményre is hatást gyakorolnak a szervezetben.

Kutatási célunkhoz az esettanulmány módszer illeszkedik a legjobban, ugyanis a stratégiai tervezés folyamata,

\section{A vizsgált egységek legfontosabb adatai és az adatgyűjtés jellemzői*}

\begin{tabular}{|c|c|c|c|}
\hline & Első egység & Második egység & Harmadik egység \\
\hline & \multicolumn{3}{|c|}{ Üzleti adatok } \\
\hline $\begin{array}{l}\text { Vállalat/üzem foglalkoztatotti } \\
\text { létszám (fö) }\end{array}$ & $100000 / 1500$ & $2000 / 1000$ & $200000 / 1000$ \\
\hline Ellátási lánc pozíció* & TIER 2 & TIER 2/3 & TIER $1 / 2$ \\
\hline $\begin{array}{l}\text { Gyártóegységben a } \\
\text { folyamatinnováció koordinációja }\end{array}$ & $\begin{array}{l}\text { központi lean program, helyi lean } \\
\text { csapat }\end{array}$ & helyi lean szakértő & $\begin{array}{l}\text { központi lean program, helyi } \\
\text { lean csapat }\end{array}$ \\
\hline \multirow[t]{2}{*}{ Digitális osztály } & igen (lean osztály részeként) & nincsen önálló egység & $\begin{array}{c}\text { igen (lean osztály ezen osztály } \\
\text { része) }\end{array}$ \\
\hline & \multicolumn{3}{|c|}{ Adatgyüjtés jellemzői } \\
\hline Interjúalanyok száma & 6 & $3 * *$ & 3 \\
\hline Dokumentumok & \multicolumn{3}{|c|}{ igen } \\
\hline $\begin{array}{l}\text { Szakdolgozat témavezetés } \\
\text { i4.0 témában / korábbi kutatás }\end{array}$ & igen / igen & nem / igen & nem / nem \\
\hline Gyárlátogatás & igen & igen & nem \\
\hline
\end{tabular}

*Az összeszerelő autógyártól vett távolság; a tier 1 a közvetlen beszállító

** 5 további interjú a vállalat más gyártóegységeiben 
illetve a szervezeti változások csak részletes interjúk és helyszíni látogatások által ismerhetők meg. Az általánosíthatóság korlátozottsága ellenére ezen területek megismeréséhez a jelenség történetének megismerése, illetve részletes és egymástól különböző információforrások szükségesek, hogy leírhatóvá váljon egy új jelenség (Leonard-Barton, 1990).

Három Magyarországon működő gyártóegységről gyűjtöttünk adatokat. A gyártóegységek autóipari beszállítók, mindegyik elektronikus alkatrészeket állít elő. Az ágazat idehaza a digitális átmenet szempontjából a legérettebb feldolgozóipari ágazatok között van (Losonci, Takács, \& Demeter, 2019). A gyártóegységek megkeresésénél fontos szempont volt, hogy átlag feletti elköteleződést mutassanak az I4.0 irányába. A három egység közül kettő nemzetközi nagyvállalat hazai gyártóegysége, amelyek élenjáróak a digitális transzformációban idehaza vagy akár divíziójuk belső hálózatában is. Mindkettő saját digitális osztállyal múködik. Fontosnak gondoltuk, hogy magyar tulajdonú cég is helyet kapjon az elemzési egységek között, mert ezen cégeknek - akár még a hazai átlag feletti technológiai színvonal mellett is - mások a lehetőségeik.

Az adatgyüjtés egységesítéséhez kialakítottunk egy adatgyüjtési protokollt, továbbá félig strukturált interjúkérdéseket írtunk. A 2018. június és 2019. május között lezajlott vállalati interjúk során elsődlegesen a vállalati és adott egység szintű változásokra, illetve konkrét projektek részletes bemutatására fókuszáltunk. Az interjúalanyok menedzserek (ha volt, akkor a digitális osztály vezetője), felső vezetők (pl. ügyvezetö) és szakértők voltak. Egy interjú átlagosan egy órás volt. Valamennyi interjút legépeltük. Az interjúkat két vizsgált egységnél is üzemlátogatás követte, ahol az interjúban ismertetett projekteket mutatták be. Az így szerzett ismeretek és a nyilvánosan elérhető információk alapján minden egységről esetleírás készült. Az első egységnél az elérhető információk körét bővítette, hogy az egységgel több évre visszanyúló szoros kapcsolat alakult ki (pl. másik kutatási projektben való részvétel, szakdolgozatírók). Az elemzések alapját az esetleírások adják.

A következőkben a kutatási modellben megjelenő pontok szerint mutatjuk be az egyes egységeket.

\section{Az autóipari kontextus és az esetek bemutatása}

A globális autóipar jelentős változásokon megy keresztül. Ezeket a változásokat leginkább négy - egymással szorosan összefüggő - trend köré szokták csoportosítani: önvezető autók fejlesztése, elektromos autók térhódítása, jármüvek hálózatba kapcsolása és a megosztás alapú technológiák terjedése (Miel, 2018). E négy trend alapjaiban forgatja fel az autóipari erőviszonyokat. Új szereplők jelennek meg más iparágakból (Google, Tesla), új beszállítók váltják fel a régieket (robbanómotorok helyett akkumulátorok), és ezek a változások tökéletesen beleillenek a negyedik ipari forradalom által generált gazdasági-társadalmi átalakulási tendenciákba. Sőt, az autóipar tulajdonképpen a főszereplő az Ipar 4.0 területén.
E nagyívü változások természetesen nemcsak a vezető autógyárakat, de beszállítóikat is érintik. Mindazonáltal, mivel Magyarországon elsősorban kis hozzáadott értékü, de nagy volumenü alkatrészgyártás és összeszerelés jellemző (Losonci et al., 2019), ezért a változások főként a termelési folyamatok optimalizálásában, kevésbé új termékek és/vagy üzleti modellek formájában jelennek meg (Demeter et al., 2019).

Gyártóegységeink közös jellemzője, hogy autóipari felhasználásra szerelnek össze elektronikai alkatrészeket. Bár az ellátási láncban elfoglalt pozíciójuk eltér, az elmúlt években az egész jármüiparban tapasztalt hatások mindegyikben érvényesültek: (1) jelentősen emelkedtek a gyártási volumenek, (2) erőteljes offshoring és outsourcing zajlott a közép-kelet-európai országok irányába, (3) a kényelmi megoldásoknak és a biztonsági elvárások emelkedésének köszönhetően a gépjármüvekben az elektronikai alkatrészek száma folyamatosan növekedett.

\section{Első gyártóegység}

Az első gyártóegység egy amerikai gyökerű multinacionális vállalat jármüipari divíziójának magyarországi leányvállalata. A TIER 2 pozícióban lévő magyarországi gyárban 1500 fö dolgozik. A gyártóegység termékkörére egyszerre jellemző a nagy termékválaszték (2800 aktív termék), a jelentős méretbeli (nanotechnológiától akár a 10 méteresig) és gyártási volumenbeli különbség (néhány darabtól milliós darabszámig). Az elmúlt években az összes gyártási darabszám erőteljes növekedése mellett szélesedett a termékválaszték, illetve a keresleti mintázatokban erős ingadozást tapasztaltak. A gyártás és az összeszerelés magas szinten automatizált. A gyártócég tevékenységét a rövid termékutak (sokszor egy gép) jellemzik. A gépeket manuálisan szolgálja ki az anyagmozgatás.

A gyártóegység digitalizációs transzformációja 20122013 körül kezdődött. A kezdetekben informális, alulról építkező stratégia jellemezte az átmenetet. Az első kezdeményezéseket a gyártóegységben a lean osztály vezette. Az első projektek a termelésben a digitális andonhoz és a digitális dashboardhoz kapcsolódtak. Ezt megalapozandó több ezer szenzort telepítettek a gépekbe. EMEA régión (Europe, Middle-East and Africa) belüli koordinált erőfeszítésekre 2014-ben került sor. Ekkor a régiós lean vezetők egy workshopon 6-8 kulcstéma köré építve kijelölték a fejlesztési irányokat. A megvalósítást két mintagyárban kezdték el, amelyek közül az egyik a magyar gyártóegység volt. A magyar egység az IoT szellemiséget ültette bele az operátorok képzési rendszerébe (Operator's Learning Management System, OLMS). Az OLMS folyamatosan ellenőrzi a munkavállalók képzettségét és a gyártási tevékenységhez szükséges ismereteket. Azok hiányában a dolgozó nem használhatja a gépet addig, amíg a munkavégzés helyéhez közeli terminálon az on-line tréninget el nem végzi. Elektronikus alapokra helyezték a problémajelentési és -megoldási rendszerüket (electronic Quality Control Process Chart, e-QCPC). A megvalósításhoz a lean osztály IT-szakértőket vett igénybe, illetve saját munkavállalóit is képezte ( $\mathrm{pl}$. az e-QCPC programozását az egyik lean csapattag végezte el). Ebben az időszakban 
indult el a Big data elemzés használatát célzó prediktív karbantartás pilot projektje. A 3D nyomtatás is megjelent a gyárban, bár nem folyamatfejlesztési célzattal, hanem a kereskedelmi, értékesítés utáni tevékenységek támogatására. Az adatok tárolására saját szervereket használnak. Összefoglalva megállapítható, hogy az alulról építkezés időszakában a gyártóegységek azon digitális megoldásokat helyezték elötérbe, amelyekkel még többet tudtak kihozni lean rendszerükből. A fejlesztések dominánsan képessé tevő technológiákra építettek, nem az emberek kiváltására törekedtek.

Az alulról szerveződő koordináció időszaka 2017-ig tartott. 2017-től a divízió szintjére került és formális (topdown) tervezés tárgya lett a digitális átmenet. Egy globális tanácsadó cég által támogatott hathetes stratégiai egyeztetést követően megszületett a központból koordinált útvonalterv (roadmap) és kialakították a globális kormányzási struktúrát is. Az elköteleződés jeleként értelmezhetö, hogy az addig 13 - döntöen lean alapú - elemre épülö többgyáras fejlesztési programba (multi-plant improvement program) 14. elemként bekerült a digitális termelés.

A digitális átmenetet a divízióban globálisan a digitális vezető irányítja, munkáját regionális bajnokok (champions) támogatják. Ezek a bajnokok az I4.0 technológiákban jártas regionális akcelerátorokkal dolgoznak. 3 fó dolgozik digitális akcelerátorként az EMEA régióban. A gyártóegységekben egy-egy digitális projektben négy kolléga vesz részt: (1) a gyártási technológiát mélységében ismerő helyi szakértő (subject matter expert), (2) a helyi digitális akcelerátor, aki a digitális technológiákban ismeri ki magát, (3) a projektmenedzser, aki jellemzően a lean osztályról kerül ki és (4) az üzleti és megtérülési szempontokat érvényesítő helyi digitális vezető. A helyi digitális vezető, aki egyben a lean osztály vezetője, fontosnak gondolja a képességek fejlesztését, és hogy legyen meg a cégen belül az I4.0 technológiák használatához a kompetencia. A programozási, adatelemzési tréningek mellett projektmenedzsment-képzést is szerveztek az alkalmazottaknak. A szakértők képzése mellett kiemelt figyelmet szentelnek a fejlesztések által érintett dolgozók véleményének becsatornázására.

2018-ban finomítottak a divízió stratégiáján, aminek fó oka az volt, hogy egyértelmübbé akarták tenni a projektek értékteremtéshez való hozzájárulását. Ez az irányváltás a magyarországi gyártóegységben tartott értékteremtési workshophoz kapcsolódik. Arra jutottak, hogy túl sokféle témában futnak a projektek és kevéssé biztosak a pénzügyi megtérülésben. A meglévő tapasztalatokra építve elhatározták a business case-ek dokumentálását (megosztását) és standardot alakítottak ki a pilot projektek tervezésére. Döntöttek a projektmenedzsment-ismeretek bővítéséről is a lean/digitális osztályok munkatársai körében. Az üzletági szintű célokat regionális szintre bontották vissza.

A divíziószintű formális tervezés több erőforrást, magasabb szakértelmet és mélyebb koordinációt biztosított. Adottak a feltételek a tudásmegosztáshoz is. Felkarolták az alulról építkezés időszakának irányvonalát és azt intézményesítették. Erre utal a lean program kibővítése és a lean osztályokhoz rendelt felelősség. A digitalizáció gyár- tási fókusza megmaradt, de az utóbbi hónapokban már az ellátási láncban, az értékesítés- és termeléstervezésben is digitális erőfeszítéseket tesz a cég. Egyelőre a funkciók közötti koordinációról még nincsen szó. A magyarországi egységben az üzemi logisztika automatizálása is fókuszba került.

\section{Második gyártóegység}

A második gyártóegység egy magyar tulajdonú feldolgozóipari vállalat egyik leányvállalata. A vállalat saját márkával nem rendelkezik, szerződéses gyártóvállalat. A vállalat árbevételében legnagyobb és az elmúlt években egyre növekvő arányban van jelen a jármüipar. A gyártóegység a vállalat legnagyobb leányvállalata (árbevételben, létszámban), amelyben kizárólag járműipari elektronikus alkatrészeket gyártanak, szerelnek össze. A gyártóegység az elmúlt években megduplázta árbevételét. A gyártóegység TIER 2/3-as pozíciót foglal el az ellátási láncban. Termékportfóliójának meghatározó részére jellemző, hogy nagy választék - alacsony volumen kategóriába esik és jelentős a manuálismunka-igénye. Nagy automatizáltságú gyártósorokkal is rendelkeznek, de az ezeken futó, nagyobb volumenü termékek aránya kisebb a portfólióban.

A vállalat központjában önálló egységként tekintenek az egyes leányvállalatokra. Emellett azonban erős tulajdonosi kontroll is jellemző, pl. beruházási döntések, üzletszerzések esetén. A vállalat egészét a „konzervatív” befektetési politika jellemzi, amelyet a gyors megtérülés és a vevői igények kielégítése is áthat. A függetlenség azt is jelenti, hogy bár a folyamathatékonyság kulcskérdés egy szerződéses gyártónál, ezen a területen nincsen elmélyült koordináció az egységek között. Így formális stratégia sem a lean alapú fejlesztésekre, sem az Ipar 4.0 szellemiségű fejlesztésekre nincsen.

Az I4.0 koncepció előtérbe kerülése okán 2018-ban sor került egy felsővezetői egyeztetésre. A vizsgált gyártóegységben a helyi szinten, a vevői igények kielégítésére és a konkrét problémák megoldására hozott döntésekből áll össze a stratégiai irányultság. Az elmúlt években képessé tevő és helyettesítő technológiákkal is volt tapasztalatuk.

A gyártóegység kiemelten kezeli a nyomkövetési rendszer alapjaira épített MES (Manufacturing Execution System) rendszert. A nyomkövetési rendszert eredetileg egy konkrét vevő elvárására fejlesztették ki. A fejlesztést az egység szakemberei végezték el, sok évvel ezelőtt. A rendszer adott termék összeszerelési lépéseiről és a beépülő alkatrészekről gyűjt információkat. E rendszert fokozatosan egyre több termékre és elöállítási folyamatra (munkaállomásra) terjesztették ki. Minőségi váltást az okozott, amikor az egyik beszállítótól vett automata gépsorokba programozott folyamatmutatókkal (pl. gépek kihasználtsága, ciklusidők, egyének ciklusideje, gépen a problémák számbavétele, OEE - Overall Equipment Effectiveness - mutató stb.) is kibővítették az addig csak nyomkövetésre szolgáló rendszerüket. Ezt a fejlesztést is a mérnökség szakemberei végezték el. Innentől a nyomkövetési rendszer valójában a munkavégzés tervezését és monitorozását támogató eszközzé vált, amelyben további fejlődést az jelentett, amikor 
a központ közremüködésével egy új, adatvizualizációban is megfelelő minőséget biztosító platformra tértek át (ez a platform több gyártóegységben is használatos). A rendszer a munkaállomásokra telepített szenzorok, az automata gépekben lévő szenzorok és a munkaállomásokon található beviteli egységek által gyűjtött információkat továbbítja a vezetők felé. A rendszert a területi vezetők igényei alapján folyamatosan finomították, fejlesztették az egység mérnökségen dolgozó szakemberei. A végeredmény egy olyan MES-rendszer lett, amely döntően a gyártási terület vezetői (középvezetők, menedzserek) és a központ felé szolgáltat adatokat.

A helyettesítő technológiák közül (hagyományos ipari) robotot alkalmaztak az egyik nagy volumenben öszszeszerelt terméknél. A robot installálásánál egy integrátorral dolgoztak közösen. A robot munkába helyezéséért is a mérnökség volt felelös. A projekt gyors megtérülést ígért, viszont a sok technikai nehézség miatt az eredeti tervekhez képest sokkal lassabban tudták lezárni. A telepített összeszerelő robot az elkészült terméket ellenőrzi is, és M2M (machine-to-machine) kommunikációval értesít egy robotkart, ami a hibás terméket leveszi a futószalagról. Bár több integrátorcéggel is dolgoztak további robotok installálásával kapcsolatban, a gyártóegységben további robotokat nem tudtak volna gazdaságosan használni. Ennek egyik oka a kis sorozatnagyság, de szerepet játszik benne az alkatrészek nem megfelelősége (pl. tág toleranciaszintek, nem robotra tervezett alkatrészek).

\section{Harmadik gyártóegység}

A harmadik gyártóegység egy nagy, nyugat-európai központtal müködő autóipari vállalat magyarországi leányvállalata. A magyar gyár az üzletág egyik legnagyobb egysége. A gyár által előállított elektronikus alkatrészek egy része TIER 1, másik része TIER 2 pozícióban kerül a vevőkhöz. Az elmúlt években folyamatosan bővülö egységben több mint 1000 fö dolgozik.

A divízióban néhány évvel ezelőtt kidolgozták a digitális termelési stratégiát (a digitális gyár koncepciót). A stratégia formális (erősen top-down szemléletü) és nagyon konkrét technológiákkal kapcsolatban fogalmaz meg adoptálási ütemtervet. E koncepció központi eleme, hogy high-tech IT-környezet kiépítését célozza meg és világossá teszi azt is, hogy digitális kompetenciával bíró szakértőkre van szükség. A stratégia megvalósításának előrehaladását és az I4.0 megoldások bevezetését KPI-rendszer méri. A koncepció fókuszában elsősorban a folyamatok hatékonyságának javítása áll. Az egység egyik határozott célja, hogy a közeljövőben azonos létszám mellett duplázzák meg az árbevételt. Úgy vélik, hogy ez a cél a digitális termelésre építve érhető el.

A digitális gyár koncepció eltérően gondolkodik az egyes I4.0 technológiák és megoldások bevezetésének üteméröl. A koncepció megvalósításán a helyi digitális osztály és a kiválósági központok együtt dolgoznak. A kiválósági központok egy-egy technológiában mélyednek el és az egyes gyárakban működnek (de azoktól szervezetileg függetlenül). A kiválósági központok kísérleteznek adott technológiával (pl. újdonságokat tárnak fel, beszál- lítókat és megoldásokat választanak ki) és rendelkeznek megfelelő tudással a hálózati bevezetés támogatásához. A helyi digitális osztály a gyártóegység szintjén dolgozik a koncepció megvalósításán, elsősorban a folyamatfejlesztésre fókuszálva. A digitális osztály folyamatfejlesztési orientáltságát jelzi, hogy a vizsgált egységben a lean csoportot is ebbe az osztályba olvasztották. Maga a lean csoport is nyitott a digitális megoldások hasznosítására, pl. folyamatszimulációt használnak a folyamatok tervezésére. Szervezetileg a digitális osztály elkülönül az IT-osztálytól. Az IT-osztálynak a transzformációhoz szükséges alapinfrastruktúra (MES-rendszer, hardverek) megteremtésében van kiemelt szerepe. Bizonyos technológiákat, kiemelten a 3D nyomtatást a gyártóegység egyes üzemei önállóan használnak.

Az elmúlt években üzemi szinten a mindennapos müködés részévé váltak a robotok (pl. vezető nélküli jármüvek (automated guided vehicle - AGV), a 3D nyomtatás és a riportálási rendszer. A gyárban több tucatnyi robotot használnak. E technológia minél kiterjedtebb használata tekinthető a legfontosabb irányvonalnak. Az első robotokat még integrátor vállalatokkal közösen helyezték üzembe. Mára az egységben rendelkezésre áll a tudás a robotok installálására. A 3D nyomtatás elsősorban a gyártóegységen belüli üzemekben használt a nem termelési anyagok előállítására. A riportálási rendszer a MESben gyüjtött adatokat dolgozza fel, és főként a transzparenciát és döntéselőkészítést segíti. A gyártóegység MES-rendszere a belső hálózatban az egyik legfejlettebbnek tekinthető. A technológiák használatát kiterjedt oktatás támogatja minden szinten.

A robotizálást fókuszba helyező folyamatfejlesztés egyértelműen a helyettesítésről szól, illetve a költségcsökkentésről. A várakozások szerint a fejlesztések hatására a gyártásban a direkt létszámban már nem várható változás. Az újabban elnyert gyártási projektek robotizált sorokon valósulnak meg, amelyeknek minimális lesz a létszámigénye. A létszámra gyakorolt hatást középtávon két dolog határozza meg: (1) milyen gyorsan futnak ki a mostani termékek, amelyek gyártósora nem robotizált és mennyiben várható, hogy helyüket robottal gyártható termékek veszik át, (2) ma a föfutó termékek robotizálása tünik gazdaságosnak, kérdéses, hogy a robottechnológia fejlődése (és a bérek emelkedése) menynyire ösztönzi más termékek gyártásának robotizálását. A gyártósorokat tervező digitális osztály munkatársai körében az alap (sok esetben a haladó) programozói ismeretek nélkülözhetetlenek. A gyártósor üzemeltetéséhez szükséges kompetenciákban is várható változás, amely a folyamatmérnökök kiválasztását, képzését érintheti. A gyártóegységnek még kevés tapasztalata van a teljesen robotizált sorok üzemeltetéséröl.

\section{Gyártóegységek összehasonlító elemzése}

Vizsgált egységeink az I4.0 megvalósítása során eltérő utat jártak be, mégis sok hasonlóságot mutatnak. A fontosabb megállapításokat a 3. táblázat szedi össze, a bejárt utakat a 3. ábra szemlélteti. 
Stratégia. A gyártóegységek vizsgálata alapján azt láttuk, hogy az Ipar 4.0 vagy digitális gyártás nagyrészt a folyamathatékonyság fejlesztéséhez kapcsolódik. Ha elő is kerülnek a gyártási (pl. 3D nyomtatás) vagy minőségmenedzsment terén technológiai innovációk (pl. 3D kamera), az alkalmazott megoldások és az I4.0-hoz kapcsolódóan azonosítható interjúalanyok szervezeti helye is a folyamatinnovációs megközelítést erősíti (López-Gómez et al., 2018). Tekintettel arra, hogy valamennyi vizsgált gyártóegység lényegében szerződéses gyártóként működik, a folyamatinnovációra fókuszáló felhasználás nem meglepö.

Az általunk vizsgált egységek legjobb esetben is csupán korai adoptálóknak tekinthetők úgy, hogy a gyártási ágazatok közül a járműipar és elektronika élenjár a digitális átmenetben, ráadásul a két nemzetközi hátterű gyártóegység a belső hálózatokban is az élmezőnyben van. Ez sokat elárul az I4.0 jelenlegi szintjéről, alátámasztva Losonci és szerzőtársai (2019) eredményeit.

Mégsem mondható, hogy az új technológiák a versenyelőny szerzéséről szólnának. A fejlesztéseknek mindegyik egységben némileg más a motivációja. Az első egységben a teljesítmény szinten tartása is kihívást okoz a növekvő választék és a fluktuáló kereslet miatt, a digitális gyár ebben segíthet nekik. A második egységben a pozíciók megtartása folyamatos költségcsökkentést követel meg, így az ezt szolgáló bármilyen fejlesztés zöld utat kap. A harmadik egységben pedig a stratégiai célokat támogatja: a munkatermelékenység kétszeresére növelésének egyik eszköze. Mindez jól alátámasztja a kontingenciaelméleti megközelítés relevanciáját és a stratégiaalkotás elsődleges szerepét (Lewis \& Boyer, 2002).

Középtávon a gépkocsieladások számának hullámzása mellett is inkább növekedéssel számolnak a cégek, mivel a kényelmi és biztonsági megoldások egyre fajsúlyosabb elektronikai támogatást igényelnek. A gyártócégek kiszolgáltatottsága emellett is jelentős, ami a technológiai lehetőségekre építő új jármüipari üzleti modellek esetleges térhódításának tudható be (Cséfalvay, 2017). Bár ezekre a kockázatokra expliciten nem tértünk ki az interjúban, az interjúalanyok sem hozták fel.

Szervezet. Azonos ágazatban müködő, de méretük és ellátási lánc pozíciójuk miatt is eltérően szervezett gyártóegységeknél vizsgálódva azt tapasztaljuk, hogy bár eltérően kezelik az Ipar 4.0-t, az végül minden egységnél „beleolvad” a már működő szervezeti rutinokba. A második gyártóegységet mindig is az informális tervezés jellemezte és ebben az Ipar 4.0 nem hozott változást: a mérnökség feladatai közé kerülnek be a technológiai kérdések, programozási feladatok. Az első és a harmadik egységnél néhány éve formális és top-down digitális stratégiát alakítottak ki, miközben egyértelmü, hogy ezekre a cégekre amúgy is jellemző volt a fejlesztési erőfeszítések ilyen természetű koordinációja. E két vállalat ennek szellemében járt el a vállalatkormányzási rendszer alakításánál is: kijelölték divízió, régiós és helyi szinten a szakértőket, vezetőket, osztályokat. Mindazonáltal árnyalatnyi különbség felfedezhető a két egység között. Az első több teret enged a helyi kezdeményezéseknek, több a kísérlete- zés, a pilot, amit rugalmas szervezeti struktúra támogat. A harmadik egység kötöttebb szervezeti struktúrában és határozottabb stratégia mentén müködik. Ez a különbség összhangban van Zaltman és szerzőtársai (1973) meglátásával, miszerint az innováció adoptálási fázisában (ld. első egység) az organikus, decentralizált, míg végrehajtási fázisban (harmadik egység) a mechanisztikus struktúra a célravezetőbb.

A vizsgált szervezetek digitális érettségét tekintve a második egység még az opportunista szinten található (Gauger et al., 2017), csak a gyorsan megtérülő lehetőségeket használja ki. Az első és harmadik gyáregység már teljesítette a transzformer szintet, hiszen mindkét gyárban van digitális igazgató, és a pacemaker bizonyos elemeit is megvalósította, hiszen vannak kiválósági központok, de egyik sem indult el a digitális termék irányába. Gyártóegységek lévén kérdéses, önmagukban elérhetnek-e egyáltalán erre a fokra, vagy ez csak a globális vállalat szintjén értelmezhető.

Technológia. A vizsgált egységekben számos technológiát használnak vagy kipróbáltak legalább pilot szinten. Az I4.0 ígérete a valódi összeköttetés, a gépek közötti kommunikáció, amelyet az IoT testesít meg. Az IoT azonban nagyon korlátozottan van jelen. IoT-ra példaként az első gyártóegység OLMS-e emelhető ki, bár ez is egy elszigetelt alrendszer. Az egységek addig jutottak el, hogy a gépparkot (és kézi müveleteket) szenzorokkal szerelték fel és megoldották az adatgyűjtést és tárolást. A kapcsolat tehát kiépült, de ez még nem összekapcsoltság. Az adathalmaz egy szelektált részének döntésekhez való felhasználására már van lehetőség minden egységben. Az üzemi területen működő digitális dashboard megoldással az első egység itt is kiemelhető. Big data elemzésekre legjobb esetben is csak pilot projekt van, kész megoldás és eredmény azonban még nincsen. Érdekes módon ezek a Big data elemzések nem a gépparkon gyüjtött adatokra futnak, hanem egy-egy gép adott alkatrészére célzottan installált szenzorok által gyüjtött adatokon. A virtuális valósággal kapcsolatosan még pilot projektekről sem tudtak beszámolni a magyarországi egységek. Megállapítható, hogy bár az Ipar 4.0-val kapcsolatban gyakran hangoztatott technológiákról van szó, a gyártóegységek tapasztalata összhangban van azzal, amire az irodalomfeldolgozásban rámutattunk: ezek még kísérleti és feltörekvő érettségi szakaszban járó technológiák (Panetta, 2018). A digitálisan domináns technológiák mellett a robotokat és a 3D nyomtatást emeltük ki. A gyakorlatban alkalmazott robotok az automatizálást valósítják meg, valójában inkább a harmadik ipari forradalom, mint az I4.0 szintjét képviselik (Valenduc \& Vendramin, 2016), illetve M2M kommunikációval támogatva ténylegesen összekapcsolhatók egymással (pl. selejtet szürnek a követő munkaállomáson). A 3D nyomtatás, bár ismert és érett technológia, a gyártóegységek tapasztalata szerint nem a folyamatinnovációban használatos.

Az alkalmazott technológia orientációja szerint markánsan eltérnek a gyártóegységek. Az első egység a képessé tevő megoldásokat használja. Ez transzparensebb folyamatokat, adatalapú és gyorsabb döntéseket jelent. 
A folyamatinnováció motorja eddig a lean rendszer volt, és a digitális megoldásoknak köszönhetően digitális lean rendszeren dolgoznak, amiben nem egy-egy lean elv/eszköz működik digitális alapon, hanem az egész rendszer. A harmadik gyártóegységnél az erőfeszítések fókuszában a helyettesítő technológiaként számontartott robotok állnak. Itt a cél, hogy teljesen automatizált gyártósorok váltsák fel az eddigi manuális közreműködést is igénylő gyártósorokat. Ugyanakkor azt is meg kell említeni, hogy a MES-rendszer is nagyon kiterjedt a cégnél. A második gyártóegységnél is inkább a képessé tevő MES-alapú folyamatirányítás meghatározó, a robotokkal korlátozott a tapasztalatuk. A technológiai orientáció alapján tehát eltérő fejlesztési utakat látunk, de közös jegyek is vannak. Ilyen a MES-rendszer, ami mindhárom cég törekvésében jelen van és az a tény, hogy robotokat egyelöre csak a nagy volumenben gyártott termékekhez tudnak gazdaságosan alkalmazni.

Hatások. A kétféle technológiai orientáció (helyettesítő/képessé tevő) a munkaerőre is eltérően hat. A helyettesítő technológiánál egyértelmüen az alacsonyan képzett munkavállalók kiváltása a cél, ezzel pedig a termelékenység növelése (legalábbis a munkatermelékenységé, mert a teljes termelékenység ettől nem nő). Itt két motiváció érhető tetten: a rendelkezésre álló munkaerő korlátozott száma, illetve az emelkedő bérekkel párhuzamosan csökkenő robotköltségek.

A képessé tevő technológiáknak is lehet hatása a munkaerő állományára, de itt elsősorban az áttekinthetőség és a termékek, tevékenységek, emberek nyomon követ- hetősége a meghatározó motívum. A cégek elkötelezettek ezen rendszerek fejlesztésében, mert látják a vezetők az értelmét. Ilyen orientációjú fejlesztésekkel kapcsolatban viszont a megtérülés nem egyértelmü.

\section{A vizsgált cégek által bejárt utak}

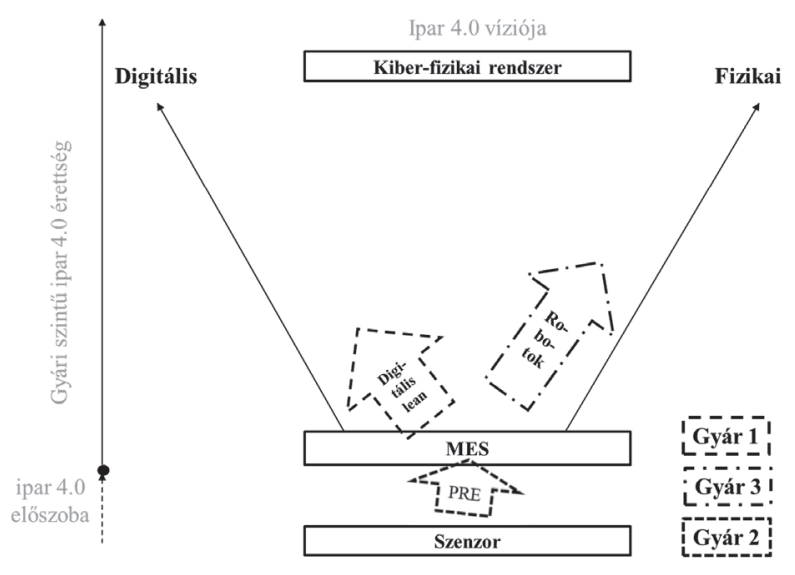

Forrás: saját szerkesztés

A kétfajta technológia bevezetése mutat hasonló jegyeket is. A programozási képességek kerülnek elötérbe a bevezetésnél. Ez a programozási képesség egyéni szinten is nagyon fontos. Mindegyik általunk vizsgált vállalat kiemelte, hogy a rendszerek fejleszthetősége miatt is szükségesnek tartják a belső kompetencia kialakítását. Bár az

Az átmenet legfontosabb jellemzői

3. táblázat

\begin{tabular}{|c|c|c|c|}
\hline Szempontok & 1. gyártóegység & 2. gyártóegység & 3. gyártóegység \\
\hline Innováció típusa & Folyamatfejlesztés a gyártásban & $\begin{array}{l}\text { Folyamatfejlesztés a gyár- } \\
\text { tásban }\end{array}$ & $\begin{array}{l}\text { Folyamatfejlesztés a gyártásban és a } \\
\text { belső anyagmozgatásban }\end{array}$ \\
\hline Stratégia & $\begin{array}{l}\text { Kezdet: informális, lentről-felfelé } \\
\text { Most: formalizált, kevert }\end{array}$ & Nincs formális stratégia & Most: formalizált, fentről-lefelé \\
\hline Technológiák & $\begin{array}{l}\text { Föként képessé tevő } \\
\text { Szenzorok, részleges IoT, saját felhő, Big } \\
\text { data megoldások (dashboard, OLMS, } \\
\text { e-QCPC) és pilotok (prediktív karbantar- } \\
\text { tás), 3D nyomtatás }\end{array}$ & $\begin{array}{l}\text { Képessé tevö és helyettesitö } \\
\text { MES, robot }\end{array}$ & $\begin{array}{l}\text { Föként helyettesitő } \\
\text { Robot, szimuláció, drón (pilot) }\end{array}$ \\
\hline Szervezet & $\begin{array}{l}\text { Kezdet: egységek laza hálózata (kísérletezés) } \\
\text { Köztes állomás: üzemek koordinált } \\
\text { eröfeszítése (pilot gyárak, kész } \\
\text { megoldások átadása) } \\
\text { Most: globális és lokális digitális kormány- } \\
\text { zás (digitális stratégia és lebontása) }\end{array}$ & $\begin{array}{l}\text { Müszaki osztály és újtermék } \\
\text { bevezetés }\end{array}$ & $\begin{array}{l}\text { Most: } \\
\text { Digitális osztály az egységnél } \\
\text { Kiválósági központ csoport (közpon- } \\
\text { ti digitális stratégia KPI-okkal) }\end{array}$ \\
\hline $\begin{array}{l}\text { Hatás a mun- } \\
\text { kaerőre (a ható } \\
\text { feladat) }\end{array}$ & $\begin{array}{l}\text { Kognitiv/manuális, repetitiv } \\
\text { (e-QCPC, dashboard) } \\
\text { Kognitiv, kreativ (Big data) } \\
\text { Nincs csökkenés a létszámban } \\
\text { Képességfejlesztés (OLMS, projektme- } \\
\text { nedzsment, adatelemzés) }\end{array}$ & $\begin{array}{l}\text { Kognitiv, repetitiv (MES) } \\
\text { Manuális, repetitiv (robot) } \\
\text { Nagyon korlátozott hatás }\end{array}$ & $\begin{array}{l}\text { Manuális, repetitív (robot) } \\
\text { Kognitiv/manuális, kreativ/repetitív } \\
\text { (szimuláció) } \\
\text { Képességfejlesztés (kibővített ké- } \\
\text { pességmátrix, robotprogramozás) }\end{array}$ \\
\hline Út jellege & Lean dominálta & Változás küszöbén & Robot dominálta \\
\hline
\end{tabular}


interjúalanyok rendre hangsúlyozták, hogy a belső fejlesztések meglátásuk szerint olcsóbbak, mint a külsők, ezt az egyszerü - számokkal alá nem támasztott - összevetést érdemes árnyalni. Valószínüleg nemcsak a költségek indokolják a belső kompetencia kiépítésének igényét, hanem az is, hogy egy-egy konkrét fejlesztés gördülékeny technikai kivitelezéshez ismerni kell a szervezet müködését, belső kapcsolatrendszerét, amit egy külsős szakértő lassan és nehezen tud megszerezni. Ráadásul így nem fordulhat elö, hogy a külső szakértő kapacitás hiányában nem áll rendelkezésre. Ezek az előnyök is közrejátszhatnak abban, hogy a cégek a belső fejlesztések irányába mozdulnak el.

\section{Összegzés}

Tanulmányunkban három gyártóegység digitális transzformációját elemeztük. Célunk az volt, hogy a digitális transzformációról egy keretrendszer segítségével átfogó képet alkossunk, és e kép alapján vonjunk le következtetéseket. Tettük mindezt azért, mert jelenleg még nem igazán található a szakirodalomban a kontextuális tényezőket is figyelembe vevő empirikus munka, márpedig ez az I4.0-val kapcsolatos ismeretek fejlődése és gyakorlati alkalmazhatósága szempontjából is elengedhetetlen. Kutatásunk fö hozzájárulásának ezért a három esettanulmány részletgazdag leírását tartjuk. Mindazonáltal az esetleírásokon túl is megfogalmazhatunk elméleti következtetéseket.

1) Folyamatinnovációs és belső fókusz. A hazai gyártóegységek döntően - ide értve a leányvállalatokat is bérgyártásból élnek, így számukra az I4.0-ban rejlő lehetőségek olyan folyamatinnovációként jelennek meg, ami segítheti a teljesítményszintek megtartását, a költségek csökkentését. A lean és az I4.0 szervezeten belüli szoros kapcsolata is ezt a megközelítést erősíti. A fejlesztések fókuszában a belső folyamatok állnak, azok közül is kiemelten a gyártás. Az értéklánc további tevékenységeire való kiterjedésnek vannak jelei, de ezek koordinációja ugyanúgy nem jellemző, mint az ellátási lánc tagok közötti kapcsolatépítés. A manapság népszerű útvonaltervek megalkotásakor (Ghobakhloo, 2018) célszerü figyelembe venni, hogy a vállalatok a fejlesztéseket jellemzően azon a területen kezdik el, ami saját értékajánlatuk szempontjából a legfontosabb.

2) Technológiák terjedése. Az I4.0 technológiák többsége még nem része a gyakorlatnak. Közös mintázat a vizsgált cégek fejlődési pályájában, hogy az adatgyüjtést és a MES rendszert alapvetőnek gondolják. Ez tehát tekinthető egyfajta nulladik lépésnek a magasabb szintekre vezető úton. A jövőben az I4.0 technológiák gyors térnyerésére számítunk. Ennek egyik oka, hogy a gyártásban a nagy nemzetközi cégek kialakították azokat a kiválósági központokat, amelyek egy-egy technológiához kapcsolódóan a sztenderd megoldásokon dolgoznak és ezeket éveken belül elterjeszthetik a hálózatokban. Szintén elömozdítja a technológiák terjedését a technológiai szabványok kialakulása, pl. a gépek kommunikációjában. Bár nem általánosítható, de az elemzett esetek arra is rávilágítanak, hogy a technológiák egy részére építve indultak el a gyártóegységek, a komplex és integrált megvalósításra azonban még várni kell.

3) Szervezeti alkalmazkodás. Bár negyedik ipari forradalomról beszélünk, a technológiahasználat jelenlegi szintjén a szervezetek meglévő rutinjaik mentén boldogulnak. Új osztályok és szakértői szerepek megjelenése jelzi, hogy az alkalmazkodási folyamat megindult, viszont az nem radikális, hanem sokkal inkább egy kiigazításnak tünik. A gyártóegységek szintjén az igazán radikális változás meglátásunk szerint akkor állhat elö, ha az I4.0-ban rejlő lehetőségeket új üzleti modellekben vagy termékekben gondolkodva használják ki. Ezt azonban nem a bérgyártó egységekben fogják a multinacionális cégek elkezdeni, kivéve, ha az adott egység kifejezetten proaktív ezen a területen.

Mit tehetnek tehát az I4.0 terén hazai vállalatok?

1) Mindenképpen célszerü foglalkozni az ellátási láncban a magyarországi egység felfelé pozícionálásával. A multinacionális cégekben a kiválósági központok praktikusan egy-egy technológiával kísérletező labort jelentenek. Egy ilyen labor a multicégen belül monopolizálja a szállítókkal való együttmüködést. Helyi szinten csak a kisebb volumenű kezdeményezéseknek marad tér! Ilyen jellegű kiválósági központok kialakítását érdemes ösztönözni, amihez viszont adott technológiában az ökoszisztéma adottságai akár meghatározóak is lehetnek. A hazai I4.0 ökoszisztéma fejlesztését tárgyalja Szabó, Horváth és Hortoványi (2019) cikke, amelyben a szerzők a vállalatok, a kormányzat és az egyetemek hálózati tanulásának lehetőségét látják hazánkban az Ipar 4.0 Nemzeti Technológiai Platform Szövetség müködésében.

2) A proaktív stratégia az okos termékek és újfajta üzleti modellek terén ugyancsak segítheti a leányvállalatokat a bérgyártó pozícióból való kitörésben. Ehhez innovatív ötletekre és felkészült, azokat a multicégen belül jól „,eladó" vezetőkre van szükség.

3) Az Ipar 4.0 előszobáján való túljutás mindegyik termelővállalat valós érdeke, ehhez pedig nagyobb hangsúlyt kell az I4.0-t támogató fejlesztésekre helyezni. Az IoT és a Big data nagyobb mértékü fejlesztése, illetve az azokból nyert adatok feldolgozása hozzájárulhatnak egy új és hatékonyabb üzleti modell kialakításához, ami a maga során pedig elhozza a nagyobb hatékonyságot, a jobb versenyképességet.

Mint minden kutatásnak, ennek is megvannak a maga korlátai. Ilyen korlát, hogy mindössze három autóipari beszállító vállalat esetét tudtuk elemezni. Ráadásul mindegyik egyfajta bérgyártó pozícióban van. Ezért következtetéseink nagy része is leginkább erre a vállalati körre alkalmazható, és a kis elemszám miatt ott is fenntartásokkal kezelendő. Bár úgy gondoljuk, hogy tanulságokat a kisebb és más pozícióban lévő vállalatoknál is le lehet vonni elemzéseinkből. Mindazonáltal a jövőben szeretnénk vizsgálódásainkat más jellegü vállalatokra, például az FMCG-szektorra, kereskedő cégekre, szolgáltató központokra, logisztikai szolgáltatókra is kiterjeszteni.

Ugyancsak jelentős korlátot képez, hogy jelenleg csak magyarországi vállalatokhoz van hozzáférésünk. A jövöben ezen is szeretnénk változtatni. 


\section{Felhasznált irodalom}

Acemoglu, D. (2016). The Impact of IT on the Labor Market. US: Massachusetts Institute of Technology. Retrieved from https://economics.mit.edu/files/12118

Acemoglu, D. (2017. May). Automation and the future of jobs. Toulouse Network for Information Technology (TNIT News). Toulouse: Toulouse School of Economics. Retrieved from https://idei.fr/sites/default/files/IDEI/ documents/tnit/newsletter/issue_17.pdf

Andersson, H., \& Tuddenham, P. (2014). Reinventing IT to support digitization. New York: McKinsey.

Baker, J. (2012). The technology-organization-environment framework. In Information Systems Theory (pp. 231245). New York, NY: Springer.

Báthory, Z. (2020). Az értékáram alapú szervezet empirikus vizsgálata öt magyarországi termelő üzem példáján keresztül. Vezetéstudomány, 51(3), 2-16. https://doi. org/10.14267/VEZTUD.2020.03.01

Brettel, M., Friederichsen, N., Keller, M., \& Rosenberg, M. (2014). How Virtualization, Decentralization and Network Building Change the Manufacturing Landscape: An Industry 4.0 Perspective. International Scholarly and Scientific Research \& Innovation, 8(1), 37-44.

Buer, S.-V., Strandhagen, J. O., \& Chan, F. T. (2018). The link between Industry 4.0 and lean manufacturing: mapping current research and establishing a research agenda. International Journal of Production Research, 56(8), 2924-2940. https://doi.org/10.1080/00207543.20 18.1442945

Carpenter, H. (2009). Gartner Hype Cycle for Emerging Technologies 2009: What's Peaking, What's Troughing? Retrieved from https://bhc3.com/2009/07/27/gartnerhype-cycle-2009-whats-peaking-whats-troughing/

Chen, Y. S., Chang, C. H., \& Wu, F. S. (2012). Origins of green innovations: the differences between proactive and reactive green innovations. Management Decision, 50(3), 368-398. https://doi. org/10.1108/00251741211216197

Cséfalvay, Z. (2017). A nagy korszakváltás. Budapest: Kairosz Kiadó.

Davies, R. (2015). Industry 4.0 Digitalisation for productivity and growth. European Union: European Parliamentary Research Service, European Parlaiment. Retrieved from http://www.europarl. europa.eu/RegData/etudes/BRIE/2015/568337/EPRS BRI(2015)568337_EN.pdf

De Toni, A., \& Tonchia, S. (1996). Lean organization, management by process and performance measurement. International Journal of Operations \& Production Management, 16(2), 221-236. https://doi. org/10.1108/01443579610109947

Demeter, K., Losonci, D., Nagy, J., \& Horváth, B. (2019). Tapasztalatok az Ipar 4.0-val - egy esetalapú elemzés. Vezetéstudomány, 50(4), 11-23. https://doi. org/10.14267/VEZTUD.2019.04.02

Donaldson, L. (2001). The Contingency Theory of Organizations. Thousand Oaks, California: Sage Publications.
Fettermann, D. C., Sá Cavalcante, C. G., de Almeida, T. D., \& Tortorella, G. L. (2018). How does Industry 4.0 contribute to operations management?, Journal of Industrial and Production Engineering, 35(4), 255-268. https://doi.org/10.1080/21681015.2018.1462863

Galbraith, J. R. (2010). The multi-dimensional and reconfigurable organization. CEO Publication T10-06 (574). Retrieved from https://ceo.usc.edu/ files/2016/10/2010_06-t10_06-Multi_Dimensional_ Reconfigurable_Org.pdf

Gartner (dátum nélk.). Gartner Hype Cycle. Retrieved from https:/www.gartner.com/en/research/methodologies/ gartner-hype-cycle

Gartner, I. (2013). Gartner's 2013 Hype Cycle for Emerging Technologies Maps Out Evolving Relationship Between Humans and Machines. Retrieved from https://www. gartner.com/technology/pressRoom.do?id=2575515

Gauger, C., Gehres, B., Quinn, M., Schmieg, F., \& Xu, G. (2017). Building the digital car company of the future. USA: The Boston Consulting Group.

Geissbauer, R., Vedso, J., \& Schrauf, S. (2016). Industry 4.0: Building the digital enterprise. Retrieved from https:// www.pwc.com/gx/en/industries/industries-4.0/landingpage/industry-4.0-building-your-digital-enterpriseapril-2016.pdf

Ghobakhloo, M. (2018). The future of manufacturing industry: a strategic roadmap toward Industry 4.0. Journal of Manufacturing Technology Management, 29(6), 910-936. https//doi:10.1108/JMTM-02-20180057

Gilchrist, A. (2016). Industry 4.0: the industrial internet of things. New York, NY: Apress.

Goran, J., LaBerge, L., \& Srinivasan, R. (2017). Culture for a digital age. McKinsey\&Company. Retrieved from https://www.mckinsey.com/business-functions/digitalmckinsey/our-insights/culture-for-a-digital-age

Horlacher, A., \& Hess, T. (2016). What Does a Chief Digital Officer Do? Managerial Tasks and Roles of a New C-level Position in the Context of Digital Transformation. IEEE Computer Society, 49th Hawaii International Conference on System Sciences, 5126-5135. https://doi. org/10.1109/HICSS.2016.63

Horváth, D., \& Szabó, Z. R. (2019). Driving forces and barriers of Industry 4.0: Do multinational and small and medium-sized companies have equal opportunities? Technological Forecasting and Social Change, 146, 119-132. https://doi.org/10.1016/j.techfore.2019.05.021

Horváth, D., Móricz, P., \& Szabó, Z. R. (2018). Üzletimodellinnováció. Vezetéstudomány, 49(6), 2-12. https://doi. org/10.14267/VEZTUD.2018.06.01

King, W. R., \& Teo, T. S. (2000). Assessing the impact of proactive versus reactive modes of strategic information systems planning. Omega, 28(6), 667-679. https://doi. org/10.1016/S0305-0483(99)00079-1

Kotha, S., \& Swamidass, P. M. (2000). Strategy, advanced manufacturing technology and performance: empirical evidence from US manufacturing firms. Journal of Operations Management, 18(3), 257-277. https:/doi. org/10.1016/S0272-6963(99)00025-X 
Lasi, H., Fettke, P., Kemper, H.-G., Feld, T., \& Hoffmann, M. (2014). Industrie 4.0. Business and Information Systems Engineering, 6(4), 239-242. https://doi.org/ 10.1007/s11576-014-0424-4

Legner, C., Eymann, T., Hess, T., Matt, C., Böhmann, T., Drews, P., \& Ahlemann, F. (2017). Digitalization: opportunity and challenge for the business and information systems engineering community. Business \& Information Systems Engineering, 59(4), 301-308. https://doi.org/10.1007/s12599-017-0484-2

Leonard-Barton, D. (1990). A dual methodology for case studies: Synergistic use of a longitudinal single site with replicated multiple sites. Organization Science, 1(3), 248-266. https://doi.org/10.1287/orsc.1.3.248

Lewis, M. W., \& Boyer, K. K. (2002). Factors impacting AMT implementation: an integrative and controlled study. Journal of Engineering and Technology Management, 19(2), 111-130. https://doi.org/10.1016/ S0923-4748(02)00005-X

López-Gómez, C., McFarlane, D., O’Sullivan, E., \& Velu, C. (2018. szeptember). The practical impact of digital manufacturing: results from recent international experience. Interim Report. Cambridge, United Kingdom: Policy Links, Institute for Manufacturing (IfM), University of Cambridge. Retrieved from https:// www.ifm.eng.cam.ac.uk/uploads/Content_Images/ IfM_IUK_Interim_revised.PDF

Losonci, D., Takács, O., \& Demeter, K. (2019). Az Ipar 4.0 hatásainak nyomában - a magyarországi jármüipar példáján. Közgazdasági Szemle, 66(2), 185-218. https:// doi.org/10.18414/KSZ.2019.2.185

Lucianetti, L., Jabbour, C. J., Gunasekaran, A., \& Latan, H. (2018). Contingency factors and complementary effects of adopting advanced manufacturing tools and managerial practices: Effects on organizational measurement systems and firms' performance. International Journal of Production Economics, 200, 318-328. https://doi.org/10.1016/j.ijpe.2018.04.005

McKinsey\&Company. (2016). Industry 4.0 at McKinsey's model factories - Get ready for the disruptive wave. McKinsey \& Company, Inc. Retrieved from https://capability-center.mckinsey. com/files/mccn/2017-03/digital_4.0_model_ factories_brochure_2.pdf

Miel, R. (2018). CASE, ACES or SAEV: What will we call electric, shared self-driving cars? Automotive News. Retrieved from https://www.autonews.com/ article/20180731/MOBILITY/180739890/case-aces-orsaev-what-will-we-call-electric-shared-self-drivingcars

Mintzberg, H., \& Waters, J. A. (1985). Of strategies, deliberate and emergent. Strategic Management Journal 6(3), 257-272. https://doi.org/10.1002/ smj.4250060306

Nagy, J. (2019). Az ipar 4.0 fogalma és kritikus kérdései - vállalati interjúk alapján. Vezetéstudomány, 50, 1, 14-26. https://doi.org/10.14267/VEZTUD.2019.01.02

Netland, T. (2013). Exploring the phenomenon of companyspecific production systems. International Journal of
Production Research, 51(4), 1084-1097. https://doi.org /10.1080/00207543.2012.676686

O'Regan, N., \& Ghobadian, A. (2002). Formal strategic planning: the key to effective business process management? Business Process Management Journal, 8(5), 416-429. https://doi. org/10.1108/14637150210449102

Panetta, K. (2018). 5 Trends Emerge in the Gartner Hype Cycle for Emerging Technologies, 2018. Retrieved from https://www.gartner.com/smarterwithgartner/5trends-emerge-in-gartner-hype-cycle-for-emergingtechnologies-2018/

Pires, G. D., \& Aisbett, J. (2003). The relationship between technology adoption and strategy in business-tobusiness markets: the case of e-commerce. Industrial Marketing Management, 32(4), 291-300. https://doi. org/10.1016/S0019-8501(02)00237-7

Porter, M. E., \& Heppelmann, J. E. (2014). How smart, connected products are transforming competition. Harvard Business Review, 92(11), 64-88.

Roland Berger (2016). Digital factories - The renaissance of the U.S. automotive industry. Munich, Germany: Roland Berger. Retrieved from https://www.rolandberger. com/publications/publication_pdf/roland_berger_tab_ digital_factories_20160217.pdf

Schlechtendahl, J., Keinert, M., Kretschmer, F., Lechler, A., \& Verl, A. (2015). Making existing production systems Industry 4.0-ready. Production Engineering, 9(1), 143148. https://doi.org/10.1007/s11740-014-0586-3

Schwab, K. (2016). The Fourth Industrial Revolution. London: Portfolio Penguin.

Slack, N., Chambers, S., \& Johnston, R. (2010). Operations management. Harlow: Prentice Hall, Financial Times.

Sousa, R., \& Voss, C. A. (2008). Contingency research in operations management practices. Journal of Operations Management, 26(6), 697-713. https://doi. org/10.1016/j.jom.2008.06.001

Stock, G. N., \& McDermott, C. M. (2001). Organizational and strategic predictors of manufacturing technology implementation success: an exploratory study. Technovation, 21(10), 625-636. https://doi.org/10.1016/ S0166-4972(01)00051-7

Szabó, Z. R., Horváth, D., \& Hortoványi, L. (2019). Hálózati tanulás az ipar 4.0 korában. Közgazdasági Szemle, 66(1), 72-94. https://doi.org/10.18414/KSZ.2019.1.72

Tornatzky, L., \& Fleischer, M. (1990). The process of technology innovation. Lexington, MA: Lexington Book.

Valenduc, G., \& Vendramin, P. (2016). Work in the digital economy: sorting the old from the new. ETUI, Brussels. Retrieved from https://www.etui.org/Publications2/ Working-Papers/Work-in-the-digital-economy-sortingthe-old-from-the-new

Viharos, Z., Soós, S., Nick, G., Várgedő, T., \& Beregi, R. (2017). Non-comparative, Industry 4.0 Readiness. Budapest: 15th IMEKO TC10 Workshop on Technical Diagnostics. Retrieved from http://eprints.sztaki. hu/9238/1/Viharos_181_3257460_ny.pdf

Zaltman, G., Duncan, R., \& Holbek, J. (1973). Innovations and organizations. New Jersey: John Wiley \& Sons. 